\title{
PENERAPAN METODE MARKET BASKET ANALISIS DALAM PENENTUAN PEMASARAN IKAN KOI (STUDI KASUS: SUMBER KOI BLITAR)
}

\author{
Refina Andini Mega Putri ${ }^{1}$, Kurnia Paranita Kartika ${ }^{2}$, Filda Febrinita ${ }^{3}$ \\ 1,2,3 Teknik Informatika S1 Universitas Islam Balitar \\ refina570@gmail.com
}

\begin{abstract}
ABSTRAK
Semakin berkembangnya teknologi internet, petani koi di Desa Sumber Blitar masih mempunyai suatu kendala dalam penjualan. Usaha koi "Sumber Koi" Blitar bergerak di bidang pembesaran bibit dan penjualan ikan koi. Penjualan sebelumnya dilakukan dengan cara membuka website sumber koi blitar di internet, instagram dan juga whatssap sehingga hanya customer tetap yang dapat mengakses. Petani di "Sumber Koi" membutuhkan suatu metode cepat untuk memperkirakan jumlah bibit, jenis bibit, dan rekapitulasi penjualan untuk mempermudah proses pemasaran ikan koi. Untuk mengatasi permasalahan ini digunakan metode (MBA) yang dapat menganalisis produk yang dibeli secara bersamaan, produk yang sering dibeli oleh pelanggan serta jumlah produk yang terbeli. Metode penelitian yang digunakan pada penelitian ini adalah metode prototype meliputi yang dimulai dari pengumpulan kebutuhan, membangun prototype, mengkodekan sistem, dan menguji sistem. Pada penelitian ini diperoleh hasil suatu aplikasi yang dapat digunakan untuk memperkirakan pemasaran ikan koi menggunakan metode Market Basket Analysis (MBA). Pengujian yang dilakukan meliputi, pengujian Black Box, pengujian ahli validator, serta pengujian pengguna. Dari pengujian Blacx Box diperoleh hasil keseluruhan fungsional aplikasi berfungsi dengan baik. Dari pengujian validasi yang dilakukan oleh 2 validator diperoleh porsentase kesesuaian hasil 77,5\%. Hasil pengujian aplikasi oleh pengguna diperoleh porsentase kesesuaian hasil 89\%
\end{abstract}

Kata Kunci: Penjualan, Ikan Koi, Market Basket Analysis, Black Box

\section{PENDAHULUAN}

Sumber Koi merupakan salah satu usaha yang dikelola oleh sekelompok petani di Desa Sumber Kecamatan Sanankulon Kabupaten Blitar. Usaha yang dilakukan oleh kelompok tani Sumber Koi meliputi pembenihan, pemeliharaan, dan penjualan Ikan Koi. Selama ini petani Koi memasarkan dengan cara tradisional dari mulut ke mulut, melalui koperasi Desa atau beberapa media social seperti facebook, instagram dan whatsapp Permasalahan yang dialami para petani adalah kurangnya media promosi yang lebih interaktif, kebanyakan petani belum dapat mengoparasikan media social serta kurangnya pengetahuan dalam memasarkan. Hal ini menghambat proses pemasaran dan penjualan Ikan Koi. Petani juga mengalami kesulitan dalam memprediksi selera konsumen terkait varian warna dan corak Ikan Koi.

Maka berdasarkan permasalahan atau uraian diatas, sangat menarik dan tepat untuk melakukan penelitian terhadap usaha budidaya ikan koi pada kelompok tani Sumber Koi dengan membuatkan Penerapan Metode Market Basket Analisis Dalam Penentuan Pemasaran Ikan Koi Studi Kasus: Sumber Koi Blitar sehingga informasi yang dihasilkan cepat, tepat, dan akurat. Solusi yang dapat diajukan untuk mengatasi permasalahan tersebut adalah menyediakan sebuah Penerapan Metode Market Basket Analisis Dalam Penentuan Pemasaran Ikan Koi Studi Kasus: Sumber Koi Blitar.
Berdasarkan uraian latar belakang diatas, maka peneliti membuat Penerapan Metode Market Basket Analisis Dalam Penentuan Pemasaran Ikan Koi Studi Kasus: Sumber Koi Blitar. Dengan adanya aplikasi ini diharapkan dapat menyediakan informasi yang cepat, tepat dan akurat sehingga dapat membantu petani dalam memasarkan produknya.

\section{TINJAUAN PUSTAKA}

\subsection{Kajian Penelitian}

Sebelum peneliti melakukan penelitian, peneliti telah melakukan beberapa kajian terkait penelitian yang telah dilakukan tentang Penerapan Metode Market Basket Analisis Dalam Penentuan Pemasaran Ikan Koi Studi Kasus : Sumber Koi Blitar, kemampuan memecahkan masalah, Berikut beberapa penelitian yang mendasari peneliti dalam melakukan penelitian tentang profil Penerapan Metode Market Basket Analisis Dalam Penentuan Pemasaran Ikan Koi Studi Kasus : Sumber Koi Blitar mahasiswa dalam memecahkan masalah ditinjau dari level kemampauan kognitif.

Pada table kajian penelitian yang mendekati dengan proposal skripsi yang akan diteliti adalah penelitian yang dilakukan oleh Andi Makkasau (2020) yang berjudul "Implementasi Metode Market Basket Analisys Untuk Mencari Pola Penjualan Makanan". Kelebihan proposal skripsi yang akan dilakukan yaitu aplikasi bisa memuat laporan penjualan, tidak hanya efektifitas media promosi saja. 
Penelitian yang digunakan sebagai acuan dalam penelitian ini adalah sebagai berikut:

Penelitian yang pertama dijadikan rujukan adalah penelitian (Kurniati, Sadikin, \& Irawan, 2019) pada tahun 2019 yang berjudul "Perancangan Sistem Informasi Penjualan Berbasis Web Pada Toko Rianata Hijab". Toko Rianata Hijab merupakan salah satu wirausaha yang menggunakan konsep yang menjual berbagai macam produk pakaian seperti baju gamis, baju koko, jilbab dan tas. Mekanisme penjualan yang sudah ada dan sedang berjalan di Rianata Hijab bersifat menunggu datangnya konsumen untuk datang ke toko fisik, sistem penjualan yang masih bersifat konvensional sehingga kurang efektif karena konsumen harus datang ke toko untuk mencari dan memilih barang yang diinginkannya. Selama ini penjualan secara konvensional belum dapat menarik keuntungan yang maksimal. Konsumen harus datang sendiri kelokasi dan pembayaran dilakukan secara tunai. Toko Rianata Hijab masih menggunakan media brosur dan banner dalam mempromosikan produk yang dirasa masih kurang dalam menyampaikan informasi detail model dari produk -produk yang dijual dan media promosi ini memerlukan modal yang cukup tinggi karena harus mengeluarkan biaya untuk menyetak brosur dalam jumlah banyak. Oleh karena itu, Toko Rianata Hijab memerlukan inovasi terbaru dalam mempromosikan produk-produk yang dijual. Perbedaan dari penelitian yang digunakan skripsi saya yaitu pada saat pemasaran melakukan menggunakan metode Market Basket Analysis sedangkan penelitian sebelumnya tidak menggunakan metode.

Penelitian yang ketiga dijadikan rujukan adalah penelitian Nuraeni \& Astuti, 2019 pada tahun 2019 yang (Pratama, Santoso, \& Fanani, 2020). Perbedaan dari penelitian yang digunakan skripsi saya yaitu pada saat pemasaran melakukan menggunakan metode Market Basket Analysis sedangkan penelitian sebelumnya menggunakan metode Waterfall.

Penelitian yang keempat dijadikan rujukan adalah penelitian Jonatan Firdaus Hutosoit (2013) pada tahun 2013 yang berjudul Menurut Jonatan Firdaus Hutosoit (2013) (dalam Samsuni \& Erifiyani2, 2018) (Samsuni1 \& Erfiyani2, 2018). Perbedaan dari penelitian yang digunakan skripsi saya yaitu pada saat pemasaran melakukan menggunakan metode Market Basket Analysis sedangkan penelitian sebelumnya menggunakan metode Bussinies to Consumer (B2C).

\subsection{Perhitungan metode MBA}

$\mathrm{A}=$ Showa

$\mathrm{B}=$ Kohaku

$\mathrm{C}=$ Sanke

1. Showa \& Kohaku

Support $=$ Jumlah item yang terjadi secara bersamaan

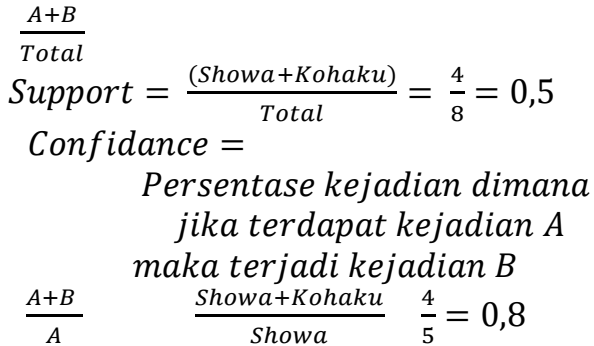

Lift ratio $=$ Persentase yang menunjukan kuat atau tidaknya suatu aturan

$0,625=\frac{0,8}{0,625}=1,28$

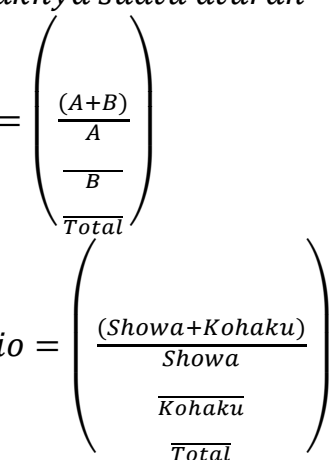

$$
\begin{aligned}
& \text { Support }=\frac{A+B}{\text { Total }}=\frac{4}{8}=0,5 \\
& \text { Confidance }=\frac{A+B}{A}=\frac{4}{5}=0,8 \\
& \text { Lift Ratio }=\frac{A+B}{A} \quad \frac{0,8}{5}= \\
& \frac{\bar{T}}{\text { Total }}
\end{aligned}
$$

2. Showa \& Sanke

Support $=$ Jumlah item yang terjadi secara bersamaan

$$
\begin{gathered}
\frac{A+C}{\text { Total }} \\
\text { Support }=\frac{(\text { Showa }+ \text { Sanke })}{\text { Total }}=\frac{4}{8}=0,5 \\
\text { Confidance }= \\
\text { Persentase kejadian dimana } \\
\text { jika terdapat kejadian } A \\
\text { maka terjadi kejadian B } \\
\frac{\text { Showa }+ \text { Sanke }}{\text { Showa }} \quad \frac{4}{5}=0,8
\end{gathered}
$$

Lift ratio $=$ Persentase yang menunjukan kuat atau tidaknya suatu aturan

$$
\begin{gathered}
=\left(\frac{(A+C)}{A}\right) \\
\text { Lift ratio }=\left(\begin{array}{c}
\text { (Showa }+ \text { Sanke }) \\
\frac{\text { Showa }}{\text { Total }}
\end{array}\right) \\
\text { Support }=\frac{A+C}{\text { Total }}=\frac{4}{8}=0,5 \\
\text { Confidance }=\frac{A+C}{A}=\frac{4}{5}=0,8
\end{gathered}
$$


$\begin{aligned} \text { Lift Ratio }=\frac{A+C}{A} & \frac{0,8}{5}= \\ 0,625=\frac{0,8}{0,625}=1,28 & \frac{\overline{8}}{\text { Total }}\end{aligned}$

3. Kohaku \& Sanke

Support $=$ Jumlah item yang terjadi secara bersamaan

$\frac{B+C}{\text { Total }}$

Support $=\frac{(\text { Kohaku+Sanke })}{\text { Total }}=\frac{4}{8}=0,5$

Confidance $=$

Persentase kejadian dimana jika terdx $\begin{array}{cc} & \text { maka terjadi kejadian } B \\ \frac{B+C}{A} & \frac{\text { Kohaku }+ \text { Sanke }}{\text { Showa }}\end{array} \frac{4}{5}=0,8$

Lift ratio $=$ Persentase yang menunjukan kuat atau tidaknya suatu aturan

$$
\begin{aligned}
=\left(\frac{(B+C)}{A}\right) \\
\text { Lift ratio }=\left(\begin{array}{c}
\frac{(\text { Kohaku+Sanke })}{\text { Showa }} \\
\text { Total }
\end{array}\right)
\end{aligned}
$$$$
\text { Support }=\frac{B+C}{\text { Total }}=\frac{4}{8}=0,5
$$$$
\text { Confidance }=\frac{B+C}{A}=\frac{4}{5}=0,8
$$$$
\text { Lift Ratio }=\frac{B+C}{A} \quad \frac{0,8}{5}=
$$

$0,625=\frac{0,8}{0,625}=1,28$

\section{METODE PENELITIAN}

\subsection{Metode Penelitian}

Metode penelitian yang digunakan pada penelitian ini adalah metode prototype dengan tahapan sebagai berikut.

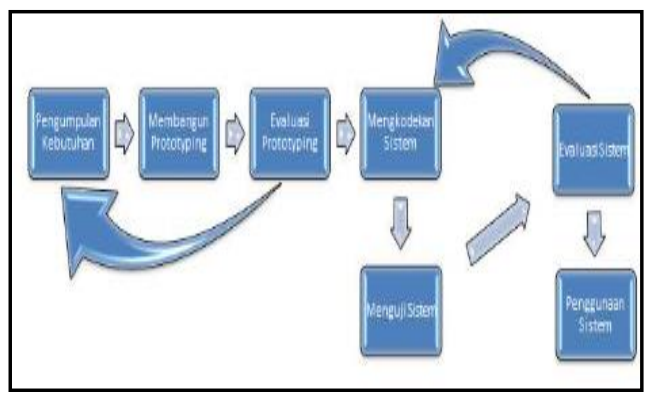

Gambar 1. Tahapan Metode Prototype

Tahapan prototype yang digunakan pada penelitian ini hanya sampai pada tahap pengujian sistem. Hal ini disebabkan karena adanya keterbatasan waktu dan biaya untuk melakukan sampai dengan tahap akhir. Berikut akan dipaparkan urutan tahapan yang akan dilakukan pada penelitian ini dengan berdasarkan pada tahapan metode prototype di atas.

\subsection{Observasi}

Metode observasi adalah suatu metode yang digunakan dengan cara pengamatan dan pencatatan data secara sistematis terhadap fenomena-fenomena yang diselidiki yaitu dapat diartikan sebagai pengamatan dan pencatatan dengan sistematik fenomena-fenomena yang diselidiki. Dalam penelitian ini penulis mengadakan pengamatan ke lokasi, untuk mengetahui berbagai permasalahan bapher liejamiąleh kelompok tani Sumber Koi di Desa Sumber.

Penjualan ikan koi tidak sama dengan penjualan ikan konsumsi, ikan koi di jual sesuai kebutuhan pembeli, ukuran ikan dapat bervariasi besar atau kecil, harga ikan koi tidak sama, tergantung kualitas corak dan warnanya. Ikan koi banyak jenisnya, yang besar belum tentu mahal, tergantung kualitas ikan. Jenis yang banyak diminati antara lain kohaku, sanke, showa, ikan berpola. Pada saat pemasaran, kendalanya ikan sebelum sampai ke tujuan atau tempat konsumen ikan, sudah ada yang mati di tengah perjalanan, ikan yang mati akan diganti. Untuk pemasaran masih manual, menggunakan social media seperti facebook dan whatsapp dengan cara mengupluod video dan gambar di social media tersebut.

\subsection{Membangun Prototyping}

Membangun prototyping dengan membuat perancangan sementara yang berpusat pada penyajian kepada pelanggan misalnya dengan membuat input dan contoh outputnya.

\subsection{DFD}

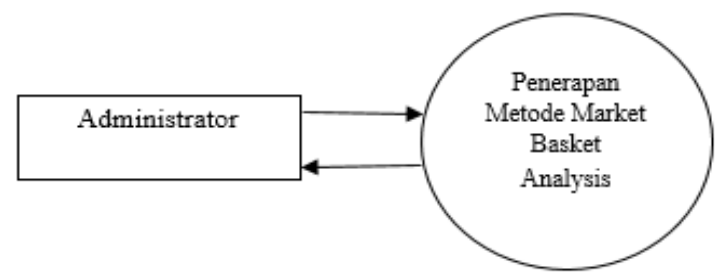

Gambar 2. DFD Level 0

Pada DFD level 0 ini menunjukkan proses Administrator kemudian menampilkan halaman utama Penerapan Metode Market Basket Analysis untuk lihat data. Karena aplikasi ini tidak membahas keseluruhan program aplikasi hanya menampilkan output metode aplikasi Market Basket Analysis. 


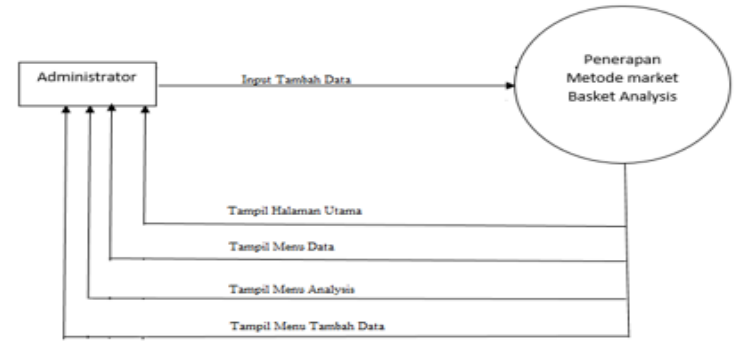

Gambar 3. DFD Level 1

Pada DFD level 1 ini menunjukkan proses Administrator kemudian menampilkan halaman utama Penerapan Metode Market Basket Analysis untuk lihat data. Ada 4 halaman, yang pertama tampil halaman utama, yang kedua tampil halaman menu data, yang ketiga tampil halaman menu analisis, dan yang keempat tampil halaman menu tambah data. Karena aplikasi ini tidak membahas keseluruhan program aplikasi hanya menampilkan output metode aplikasi Market Basket Analysis.

\subsection{ERD}

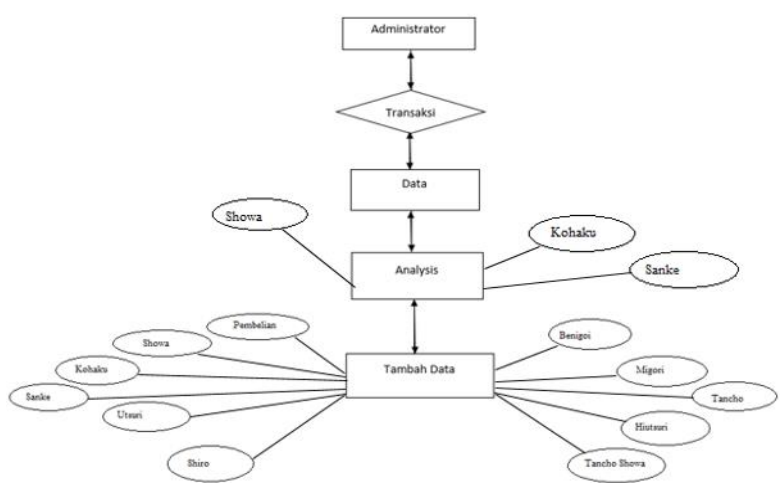

Gambar 4. ERD Perancangan Pemasaran Aplikasi Ikan Koi

\subsection{Flowchart}

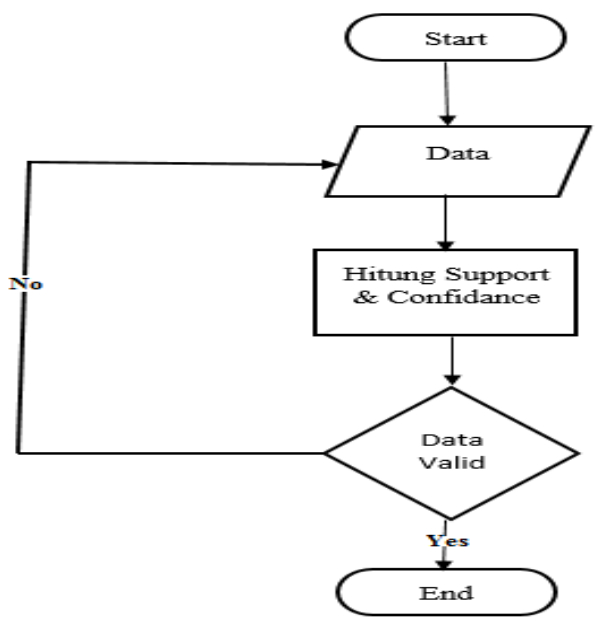

Gambar 5. Flowchart Market Basket Analysis

\subsection{Evaluasi Prototyping}

Prototype evaluasi ini dilakukan oleh pelanggan apakah prototyping yang sudah dibangun sudah sesuai dengan keinginan pelanggan. Jika sudah sesuai maka langkah keempat akan diambil. Jika tidak, maka prototyping diperbaiki dengan mengulang langkah 1, 2, dan 3. Evaluasi ini dilakukan oleh pemilik usaha ikan koi dan validator IT apakah prototyping yang sudah dibangun sudah sesuai dengan keinginan. jika sudah sesuai maka langkah keempat akan diambil. jika tidak, maka prototyping diperbaiki dengan mengulang langkah 1, 2, dan 3. Hasil evaluasi dari prototipe yang dibuat adalah prototipe dilanjutkan ke tahap pengodean.

\subsection{Mengkodekan Sistem}

prototyping yang sudah ada pada tahap ini disepakati diterjemahkan ke dalam bahasa pemrograman yang sesuai. Pada tahap ini prototipe dibuat dengan bahasa pemrograman PHP dengan konsep framework. Windows adalah sebagai sistem operasi untuk akan dipakai, Apache sebagai web server, PHP sebagai bahasa pemograman, MySql sebagai database, Adobe Dreamweaver CS4 sebagai editor, CSS sebagai script pengolah tampilan, editor penulisan-penulisan file-file $\mathrm{php}$ dan $\mathrm{html}$ (Ayu \& Permatasari, 2018).

\section{HASIL DAN PEMBAHASAN \\ 4.1. Paparan Data}

Data yang diolah dalam sistem aplikasi Penerapan Metode Market Basket Analisis Dalam Penentuan Pemasaran Ikan Koi Studi Kasus: Sumber Koi Blitar ini merupakan data dari namanama jenis ikan koi yang sering laku nantinya akan dihitung jenis ikan koi yang terjual secara bersamaan di Sumber Koi Blitar. Digunakan nama jenis ikan koi showa, kohaku, sanke dalam pencarian sistem aplikasi dikarenakan mempermudah untuk dalam admin melakukan untuk menentukan produk manakah yang beli pelanggan bersamaan dalam waktu.

\subsection{Hasil Penelitian}

Pada penelitian ini, peneliti menerapkan metode Market Basket Analysis (MBA) untuk mengenali 3 jenis ikan koi yang sering laku terjual di budidaya ikan koi yang berlokasi di Sentra kelompok tani Sumber Koi di Desa Sumber Kecamatan Sanan5kulon Kabupaten Blitar, selama tahun 2020-2021, yakni ikan koi jenis Showa, Kohaku, dan Sanke. Pada penelitian ini terdapat 3 proses yang meliputi, pembuatan model market basket analisis, pengujian metode, dan penerapanya. 


\subsection{Halaman Utama}

Hasil implementasi sistem Pemilihan Produk Terlaris pada Toko Sumber Koi Blitar terdiri dari beberapa halaman yaitu halaman menu utama, halaman data transaksi, menu analisis metode, menu tambah data. Berikut adalah implementasi halaman yang dapat diakses oleh pengguna. Pada halaman utama ini merupakan halaman utama saat masuk kedalam sistem. Pada halaman ini menampilkan beberapa menu yaitu yang pertama menu data ikan berfungsi untuk menampilkan data ikan yang terjadi penjualan sebanyak 6 kali panen selama tahun 20202021 terjadi 4 kali proses penjualan 3 jenis ikan yang sama, dan halaman analysis berfungsi untuk menampilkan jenis ikan, nilai Support, Confidance, Lift ratio, dan juga Hasil, dan yang ke tiga pada halaman tambah data berfungsi untuk mengisi data ikan adakah penjualan jenis ikan pada transaksi tersebut.

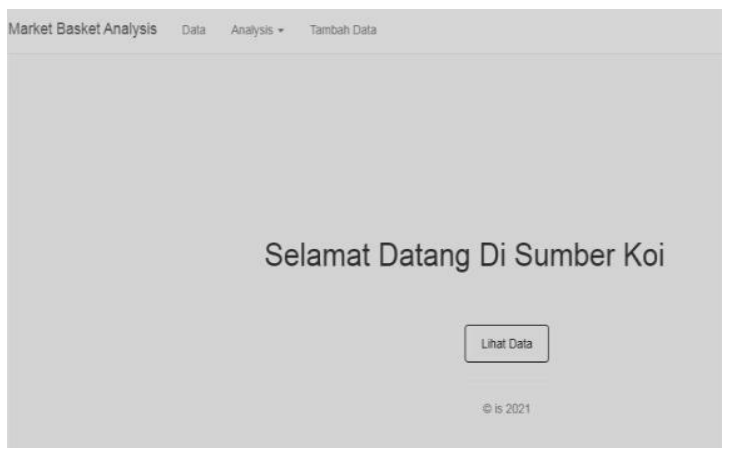

Gambar 6. Halaman Utama

\subsection{Halaman Data Ikan}

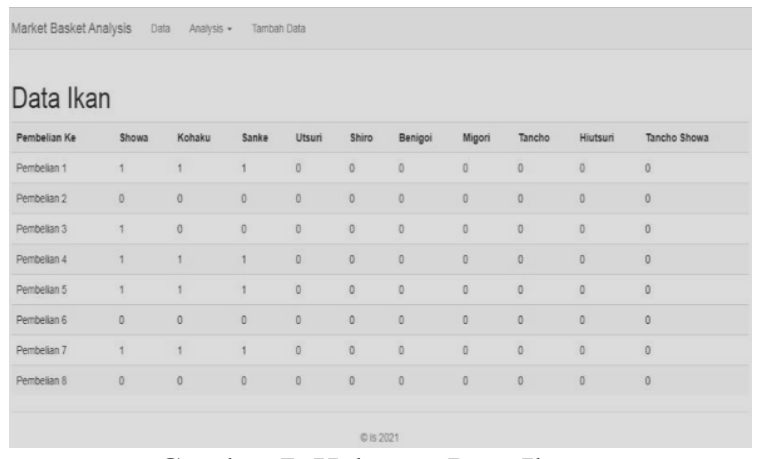

Gambar 7. Halaman Data Ikan

Halaman data ikan yaitu halaman untuk menampilkan data ikan yang terjadi penjualan sebanyak 6 kali panen pada panen 1 terjadi 2 pembelian, panen 2 terjadi 1 pembelian, panen 3 terjadi 1 pembelian, panen 4 terjadi 1 pembelian, panen ke 5 terjadi 2 pembelian, panen 6 terjadi 1 pembelian dan total menjadi 8 kali pembelian. yaitu selama tahun 2020- 2021. Panen 1 pada bulan Maret 2020 panen 2 pada bulan juni 2020, panen 3 pada bulan september 2020, dan panen 4 pada bulan desember 2020, panen 5 pada bulan januari 2021 dan terakhir panen 6 pada bulan juni tahun 2021, selama tahun 2020-2021 terjadi 4 kali proses penjualan 3 jenis ikan yang sama. Berikut yaitu tampilan halaman data ikan seperti pada gambar 7

\subsection{Halaman Analisis}

Halaman Analysis adalah halaman yang menampilkan jenis ikan koi yang sama terjual. Pada halaman ini juga dapat menampilkan nilai Support adalah jumlah item yang terjadi secara bersamaan, Confidance yaitu persentase kejadian jika terdapat kejadian A maka terdapat kejadian $\mathrm{B}$, Lift ratio adalah persentase yang menunjukan kuat atau tidaknya suatu aturan, dan juga Hasil akhir adalah direkomendasikan artinya direkomendasikan untuk dijual ulang karena hasil dari lift ratio 1,28 yang artinya lebih dari 1 .

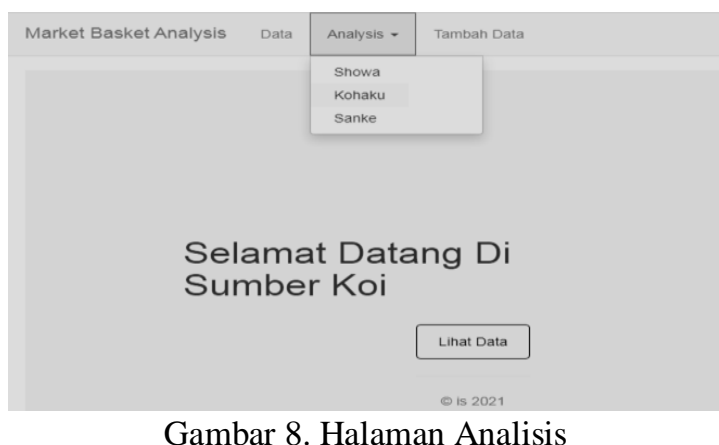

\subsection{Halaman Analisis Showa}

Halaman Analysis showa adalah halaman yang menampilkan output jenis ikan koi showa \& kohaku, showa \& sanke, yang sama terjual. Pada halaman ini juga dapat menampilkan nilai Support yaitu 0,50, nilai Confidance 0,80 , dan nilai Lift ratio 1,28 adalah persentase yang menunjukan kuat atau tidaknya suatu aturan, dan juga Hasil akhir adalah direkomendasikan artinya direkomendasikan untuk dijual ulang karena hasil dari lift ratio 1,28 yang artinya lebih dari 1 .

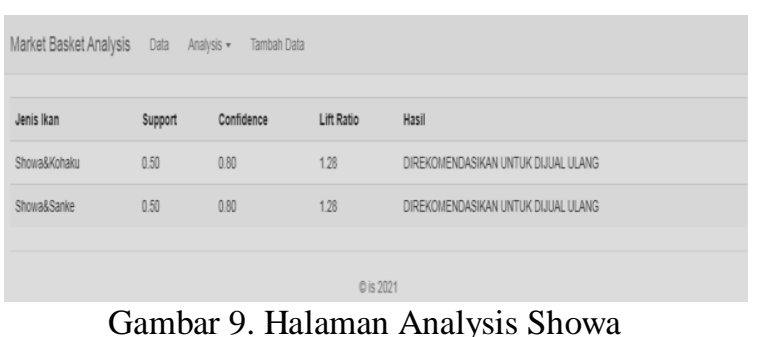

\subsection{Halaman Analisis Kohaku}

Halaman Analysis kohaku adalah halaman yang menampilkan output jenis ikan koi showa \& kohaku, kohaku \& sanke, yang sama terjual. Pada halaman ini juga dapat menampilkan nilai Support yaitu 0,50 , nilai Confidance 0,80 , dan nilai Lift ratio 1,28 adalah persentase yang menunjukan kuat atau tidaknya suatu aturan, dan juga Hasil akhir adalah direkomendasikan artinya direkomendasikan untuk 
dijual ulang karena hasil dari lift ratio 1,28 yang artinya lebih dari 1 .

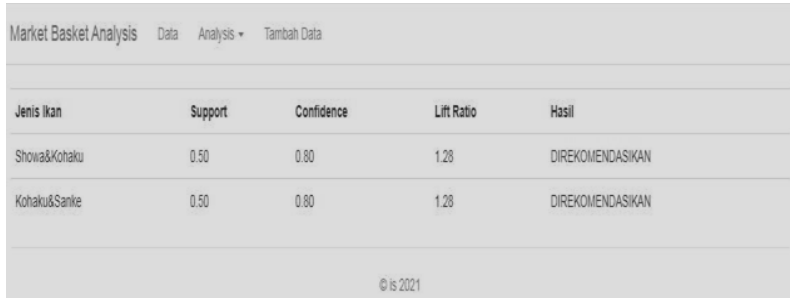

Gambar 10. Halaman Analysis Kohaku

\subsection{Halaman Analisis Sanke}

Halaman Analysis sanke adalah halaman yang menampilkan output jenis ikan koi showa \& sanke, kohaku \& sanke, yang sama terjual. Pada halaman ini juga dapat menampilkan nilai Support yaitu 0,50 , nilai Confidance 0,80 , dan nilai Lift ratio 1,28 adalah persentase yang menunjukan kuat atau tidaknya suatu aturan, dan juga Hasil akhir adalah direkomendasikan artinya direkomendasikan untuk dijual ulang karena hasil dari lift ratio 1,28 yang artinya lebih dari 1 .

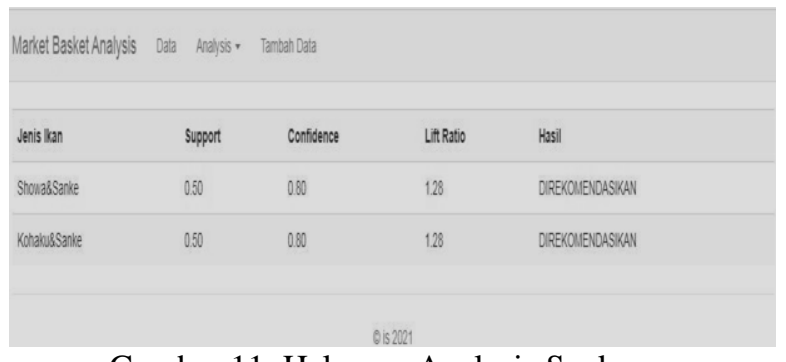

Gambar 11. Halaman Analysis Sanke

\subsection{Halaman Tambah Data}

Halaman Tambah Data adalah halaman untuk mengisi data ikan adakah penjualan jenis ikan pada transaksi tersebut. Jika terjadi penjualan maka di isi data angka 1 jika tidak terjadi penjualan di isi angka 0 . Untuk halaman tambah data yang dapat mengisiskan atau menginputkan data adalah admin atau mahasiswa. Aplikasi ini nanti dapat digunakan oleh admin atau mahasiswa sebagai ujian skripsi. Berikut adalah tampilan halaman Tambah Data seperti pada gambar 12

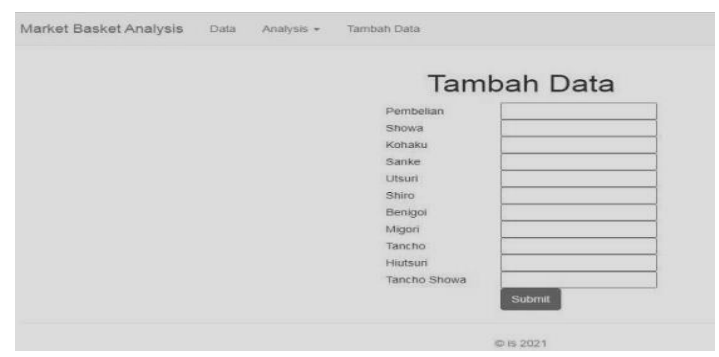

Gambar 12. Tambah Data

\section{KESIMPULAN DAN SARAN}

\subsection{Kesimpulan}

Pada penelitian ini menghasilkan kesimpulan sebagai berikut:

1. Metode Market Basket Analysis berhasil diterapkan pada pembuatan aplikasi penentuan pemasaran ikan koi dengan mempertimbangkan jumlah bibit, jenis bibit, dan rekapitulasi penjualan untuk mempermudah proses pemasaran ikan koi dengan menggunakan pemrograman php.

2. Pengujian yang dilakukan meliputi, pengujian Black Box, pengujian ahli validator, serta pengujian pengguna. Dari pengujian Blacx Box diperoleh hasil keseluruhan fungsional aplikasi berfungsi dengan baik. Dari pengujian validasi yang dilakukan oleh 2 validator diperoleh porsentase kesesuaian hasil $77,5 \%$. Hasil pengujian aplikasi oleh pengguna diperoleh porsentase kesesuaian hasil $89 \%$.

\subsection{Saran}

1. Hal-hal yang masih belum dilakukan peneliti yang terkait dengan penelitian belum menghitung jumlah pembelian semua jenis ikan hanya menghitung tiga jenis ikan yang sama yaitu showa, kohaku, dan sanke.

2. Penelitian selanjutnya yang berkaitan dengan Market Basket Analysis dapat dikembangkan dengan menggunakan aplikasi berbasis web. Selain itu, jumlah data yang lebih besar memungkinkan juga untuk mendapatkan aturan asosiasi yang lebih baik.

\section{DAFTAR PUSTAKA}

[1] Ayu, F., \& Permatasari, N. (2018). Perancangan Sistem Informasi Pengolahan Data Praktek Kerja. -: Volume 2, No.2 Oktober 2018 ISSN. 2549-0222.

[2] Bachtiar, Y. (2002). Mencemerlangkan Warna Koi. . Jakarta: AgroMedia Pustaka.74 hlm.

[3] Finahari, N., \& Alfiana. (2020). Analysis of Potential Development of Ornamental Koi Fish Business. Blitar: GANDRUNG: Jurnal Pengabdian Kepada Masyarakat.

[4] Karmila, M. (2000). Fenotipe Warna Keturunan Diploid dan Triploid Hasil Persilangan Ikan Koi (Cyprinus carpio L) Kohaku dan Sanke Betina dengan Jantan Shiromuji dan Jantan Higoi. Bogor: Skripsi Fakultas Perikanan dan Ilmu Kelautan Institut Pertanian Bogor. 44 hlm.

[5] Kurniawan, I. (2020). Perancangan Aplikasi Data Karyawan. jakarta: Jurnal Riset dan Aplikasi Mahasiswa Informatika (JRAMI).

[6] Makkasau, A. (2020). Implementasi Metode Market Basket Analysis. Jakarta: Skripsi Politeknik Negeri Jakarta. 
[7] Maulia, M. A. (2019). Analisis Pemasaran Ikan Hias Koi(Cyprinus carpio). Medan: Fakultas Pertanian.

[8] Pasaribu, S. A. (2020). Strategi Pengembangan Usaha Budidaya Hias Koi(Cyprinus carpio) Di Desa Karang Anyar Kecamatan Beringin. Medan: Tidak Diterbitkan: Skripsi Universitas Muhamadiyah sumatera Utara Medan.

[9] Pratama, F. R., Santoso, N., \& Fanani, L. (2020).Pengembangan Aplikasi ECommerceMenggunakan Payment Gateway Midtrans. -: Jurnal Pengembangan Teknologi Informasi dan Ilmu Komputer.Vol. 4, No. 4, April 2020, hlm. 1133-1140.

[10] Ramadhan, F., Matondang, N. H., \& Yulnelly. (2020). Perancangan Sistem Informasi Penjualan Ikan Air Tawar Berbasis Web (Studi
Kasus : N'Cex Aquatic). Jakarta: ISBN 978623-93343-1-4.

[11] Samsuni1, S., \& Erfiyani2, E. (2018). Rancang Bangun Aplikasi E-commerce Penjualan Produk kecantikan Dan Fashion Pada AC Fashion Style. Jakarta: e-ISSN: 2597-9922, pISSN: 2406-7733.

[12] Siregar, H. F., Siregar, Y. H., \& Melani. (2018). Perancangan Aplikasi Komik Hadist Berbasis Multimedia. -: (Jurnal Teknologi Informasi) Vol.2, No.2. Desember 2018 PISSN 2580-7927 | E-ISSN 2615-2738.

[13] Supardianto, \& tampubolon, A. b. (2020). Penerapan UCD (User Centered Design) Pada Perancangan Sistem informasi Manajemen Aset TI Berbasis Web di Bid TIK Kepolisian Daerah Kepulauan Riau. Batam : Journal of Applied Informatics and Computing (JAIC). 